\title{
Beneath the master narrative: human trafficking, myths of sexual slavery and ethnographic realities
}

\author{
Edward Snajdr
}

Published online: 2 March 2013

(C) The Author(s) 2013. This article is published with open access at Springerlink.com

\begin{abstract}
This paper explores the disconnections between anti-trafficking discourse and the local experience of responding to human trafficking as indicated in ethnographic data from Bosnia and Kazakhstan. Using the concept of "uptake," I examine how anti-trafficking discourse operates as a master narrative, drawing on techniques of emotion and logic, as well as a specific type of victim story. I also consider how, despite an emerging counter discourse that questions the data and challenges current policy, human trafficking discourse continues to be retold in media and reproduced in popular culture, often in ways that actually diverge from the current version of the grand narrative. In contrast to these uncritical representations, ethnographic data from Bosnia suggest that the master narrative is selective in how it represents the history of the problem and that it does not "take up" important details about the context that fosters sexual exploitation, despite Bosnia's compliance with US policy. Conversely, Kazakhstan suffers a liminal status regardless of local efforts to prevent the problem from happening within its borders as well as evidence that the crime is not widespread. While perhaps not mythical, I suggest that the master narrative contains the stuff of legend as it occupies the critical spaces of policy, activism and development, leaving open the question of how to address the nuances and needs of responding to victims of gender violence.
\end{abstract}

Keywords Trafficking - Kazakhstan · Bosnia - Ethnography · Sexual slavery · Narrative

E. Snajdr $(\bowtie)$

Department of Anthropology, John Jay College,

899 Tenth Ave., New York, NY 10019, USA

e-mail: esnajdr@jjay.cuny.edu 
My Bosnian driver and I froze as the EUFOR ${ }^{1}$ guard aimed his M-16 directly at our windshield after we had made a wrong turn among the maze of barbed wire and concrete barriers zigzagging before the entrance to Eagle Base on the outskirts of Tuzla. The Austrian soldier continued to train his weapon on us as I gingerly held out my US passport from the passenger window of our unmarked blue sedan. I cried out "I'm American! I have a meeting with Major Houston!" The winding and cryptic path into the base, the home of a multinational peacekeeping force in the aftermath of the Bosnian conflict, was indeed hard to see, as it was laid out precisely to prevent a successful terrorist car bomb attack. Upon seeing my credentials and hearing my explanation, the armed sentinel let us pass toward the main checkpoint.

I was in Bosnia and Herzegovina gathering ethnographic information on human trafficking interventions and had arranged to meet an official from the US military contingent at the base about the training of peacekeeping forces on this issue. Bosnia had been a notorious hotspot of trafficking in persons, as well as a site for coordinated responses to the exploitation of women in the illicit sex trade. I had been in Tuzla interviewing local police about their work with trafficking victims and wanted to learn about the training efforts for peacekeeping forces nearby. With our hearts still rapidly pounding from the frightening situation of being at gunpoint at the base's perimeter post, my companion and I checked in with the officer on duty at the heavily fortified front gate. After some phone calls and a bit of waiting, we learned that the public affairs officer had had to cancel, but that he had left the training materials on a CD-ROM for me. I put the item in my jacket pocket and we headed out, back to town. When I opened the slender plastic CD case, I quickly recognized that what I had come so far to see I had seen long before I had ever gotten there: the 2004 Trafficking in Persons Report, published by the US State Department. The document was readily available to anyone with internet access at "state.gov." In Bosnia, I was trying to understand human trafficking as a good ethnographer, looking for the "thick description" in the messy details of everyday human experience from which we cull meaning (Geertz 1973). Instead, at Eagle Base, and in many other ethnographic spaces, I kept finding a master narrative.

From an anthropological perspective, a master narrative is an over-arching cultural message as well as a framework of knowledge and action. Operating discursively through textual and other communicative technologies, a master narrative tries to "make normal" both ideology and action on the broadest and most pervasive levels and spheres of society. It becomes (or tries to become) the standard view, what Bamberg (2004) describes as a strategy of legitimization. Exploring how a master narrative of human trafficking as it is largely defined and utilized in the US Trafficking in Persons (TIP) Report, among other discursive sites, reveals how it serves as the standard vision and approach to the problem despite important intersections of agency, identity, culture and language. Theorizing how the technologies and practices of this dominant discourse operate and are reproduced reveals how the master narrative of the anti-trafficking "community" is both iconic

\footnotetext{
${ }^{1}$ EUFOR is the acronym for the military force led by the European Union in charge of security and stability in post-conflict Bosnia Herzegovina. EUFOR replaced SFOR in 2004 and presently serves as an advisory and support capacity in the Balkans. See Andreas (2008) for an overview of peacekeeping in Bosina.
} 
and iterative, relying upon some of the very discursive aspects for which it has been challenged, including its scope, its subject and its modes of documentation, in order to assert its dominance. I also consider how beneath the master narrative, ethnography on human trafficking can reveal subtler and more accurate appraisals of experiences and contexts that depart from the grand discourse. It can also show how some key experiences of trafficking have been left out of the official account. Drawing on research from my work as a co-director of an anti-trafficking and gender violence development project in Kazakhstan in 2003, as well as from fieldwork I carried out with a team of researchers on trafficking in persons in postconflict Bosnia in 2006, I show that the problem of human trafficking is far from monolithic, most certainly dynamic and context-based, and often linked to a host of issues that appear to be overlooked or ignored in policy making, in legislation or in advocacy for people victimized.

\section{The anti-trafficking story and its discontents}

The prevailing discourse or master narrative of anti-trafficking contains three main assumptions put forward by US officials and by many (although not all) of the NGOs who seek to assist individuals in need of help. The first premise holds that trafficking-in-persons exists on a massive and ever-increasing scale. The second premise: human trafficking is the result of a set of legal shortcomings on the part of other states. And the third suggests that the way to respond to the malady is to strengthen laws and law enforcement in as many ways as is possible and to encourage the non-profit sector to assist with helping victims. Essentially, the antitrafficking community constructs the problem of human trafficking as a global crime whose victims include not only women and children exploited by traffickers, but also the "rule of law" societies of Western Europe and North America.

One can find the iconic story of a victim of human trafficking nicely represented in a Vanity Fair article written by Junger (2002). In this account, a young Moldovan woman, we are told, was in the process of seeking a better life for herself and her family. She found an opportunity to work in Germany as a nanny, but was required to give her handlers her passport and documents. Thus, trusting but dependent upon her agents to navigate her way through East Europe, she ended up in Kosovo. Held captive, she was forced to work as a prostitute, rather than a nanny. In the article, we learn that her captivity is reinforced by multiple types of desperation and bondage. In Kosovo, the Moldovan woman, a native Russian speaker, is linguistically handicapped. She is from the poorest post-Soviet state following the collapse of communism. She is also no longer in control of her documentation or official papers. Additionally, any money that she earns from her work is kept by her boss.

The frightening details of experiences similar to the woman in Junger's Vanity Fair piece have appeared in cases around the globe, from Thailand to South Korea, and from the United Arab Emirates to Latin America. ${ }^{2}$ Whether fleeing severe

\footnotetext{
${ }^{2}$ See for example Joseph (2003) and FSU (2003) for cases from Latin America, Piper (2003) for Thailand and Utrecht (1994) for Korea and the U.A.E.
} 
poverty, confronting bitter unemployment, or escaping war-torn states, stories of exploited individuals, who leave their homes in search of hope, read as disturbing experiences of struggle, told mostly by women, who became victimized by traffickers and who somehow escaped these terrible circumstances with their lives and their tales. These victims' accounts can be found in news media, posted on the websites of NGOs working to help victims, published in reports by international and government agencies and captured in documentary films and television news shows. Along with these accounts and images, we find estimates attesting to the significant scope, frequency and growth of the problem. For example, the US State Department first reported in 2001 that "at least 700,000 people, especially women and children are trafficked each year across international borders" (TIP 2001:4). A year later the estimate given by the official US report ballooned to "as many as four million" (TIP 2002:3). Additionally, maps produced by NGOs, such as the Protection Project, ${ }^{3}$ or by international entities, such as The Council of Europe, mark the relationships of origin, transit and receiving countries, which together depict a grim atlas of global slavery.

The anti-trafficking movement actually begins quite a few years before Junger's Vanity Fair article with the 1994 Utrecht Conference on Traffic in Persons, which actually called for the decriminalization of prostitution and efforts to improve health and safety regulations for sex workers worldwide (Murray 1998). Following this international concern over the issue of sex tourism, however, there emerged what some scholars have termed an unlikely collaboration between abolitionist feminists and conservative Christian groups in the United States whose common aim is to eradicate prostitution (Berman 2006; Weitzer 2007). These two movements lobbied the US government at the end of the 1990s to create the Victims of Trafficking and Violence Protection Act (VTVPA), which Congress first passed in $2000 .^{4}$ In addition to a statutory definition of trafficking, this federal legislation inaugurated a set of official governmental responses to the problem-routinely referred to as the "three Ps"-including protection, prosecution and prevention (TIP 2001:9). ${ }^{5}$ The act also includes provisions for the funding of international and domestic NGOs and the training of law enforcement. Working in cooperation with governmental efforts is a wide array of non-governmental organizations with an equally diverse set of aims to address the "three Ps" policy. These groups include, but are not limited to, the Coalition Against Trafficking in Women (CATW), the Global Alliance Against

\footnotetext{
3 The Protection Project is a human rights research institute based at the Johns Hopkins University School of Advanced International Studies.

4 The VTVPA has been reauthorized in 2003, 2005 and 2008. The act expired on October 1, 2011, and is being considered for reauthorization in 2012.

5 The VTVPA defines severe forms of trafficking as (a) sex trafficking in which a commercial sex act is induced by force, fraud, coercion, or in which the person induced to perform such an act has not attained 18 years of age or (b) the recruitment, harboring, transportation, provision or obtaining of a person for labor or services through the use of force, fraud or coercion for the purpose of subjection to involuntary servitude peonage, debt bondage or slavery. The minimum standards of the VTVPA state that (1) a government should prohibit human trafficking and punish such acts, (2) punishment should be commensurate with the crime, (3) punishment should not only deter but also reflect the heinousness of the crime, and (4) states should make serious and sustained efforts to eliminate severe forms of human trafficking.
} 
Trafficking in Women (GAATW), La Strada, the International Justice Mission, Free the Slaves and the Polaris Project. ${ }^{6}$ One of the largest organizations focused on assisting victims of trafficking is the International Office of Migration (IOM), which receives funding from a range of sources, but notably from USAID through appropriations from the VTVPA. In addition to support for NGOs, and perhaps less known to the public, have been various US assistance efforts for the training of law enforcement and other justice officials around the globe. ${ }^{7}$

Emerging with this constellation of anti-trafficking stakeholders is a counter discourse that challenges both the data and the ideological underpinnings in the official policies of the anti-trafficking paradigm and contextualizes and critiques the role of non-governmental organizations and government that have influenced it as propagating a "moral panic" or "crusade" against sex workers (Weitzer 2007). ${ }^{8}$ For example, using the term the cultural myth of trafficking, Doezema (2000) was one of the first critics to interrogate the official story by comparing it to the White Slavery scare of the late nineteenth century and the passage and outcomes of the 1910 Mann Act, which she argues was used against sex workers and working class women as opposed to any non-Western slavers. ${ }^{9}$ Following Doezema, a few scholars and journalists have more recently challenged the veracity of the official estimates of the numbers of people trafficked annually, suggesting that such figures are at best not provable and at worst exaggerated and misleading (Fiengold 2010; Nathan 2005; Rothschild 2009; Weitzer 2012; Warren 2010). ${ }^{10}$ At the same time, critics of the anti-trafficking movement have detailed what they see as an essentially conservative stance in the battery of responses to human trafficking that is inherently against any form of prostitution and which unfairly targets individuals who follow this path of employment regardless of their circumstances (Berman 2006; Weitzer 2007; Kempadoo et al. 2005). Bernstein (2010) has also recently connected the antitrafficking collaboration between faith-based organizations and secular feminists with a broader shift in women's activism toward what she terms "carceral feminism" or the substitution of criminal justice for social justice in the pursuit of and subsequent assertions for gender rights in the United States.

\footnotetext{
${ }^{6}$ Much has been written about the politics among and between these organizations and their relationships to broader ideologies, beliefs and agendas (Berman 2006; Bernstein 2010). La Strada began as Comesha, an organization founded in 1987 in the Netherlands. There is also ECPAT International, an organization formed in 1990 to prevent the sexual exploitation of children. Free the Slaves is run by Kevin Bales a human rights activist and author of Disposable People (Bales 2004).

${ }^{7}$ For example, the Albright State Department under Bill Clinton funded gender violence assistance programs for the former Soviet Union that were first administered by the agency's Bureau for International Narcotics and Law Enforcement Affairs, which preceded the creation of the Trafficking-inPersons or TIP Office in 2001 and which were awarded to a variety of NGOs and universities. See King and Ray (2000) for an overview of international law enforcement training initiatives.

${ }^{8}$ The concept of moral panic, as Weitzer points out, is a term of social and political analysis, coming from the work of Stanley Cohen (1972) and also from Goode and Ben-Yehuda (1994). The word 'crusade' conjures up organized and militarized efforts to convert and conquer.

${ }^{9}$ Doezema notes that the Mann Act was triggered by accounts of the abduction of white women for prostitution in South America, Africa or Asia by non-Western men and that "historians are nearly unanimous in seeing that the actual [number of] cases of such abductions was quite small."

${ }^{10}$ Weitzer (2007) argues that estimates of an underground and hard to track problem such as trafficking should not even be made.
} 
Despite the tropes of "moral crusade" and "global panic," the US government, as a point of leadership and of policy, has defined its response to human trafficking in a manner evidently more purposeful than panic-driven. Using the VTVPA as a measure and the annual US TIP Report as a medium, the US government has constructed a global accounting of compliance for other nation states with regard to trafficking. In addition to victim's stories and country summaries, the annual TIP report contains a ranking of countries. Countries whose governments fully comply with VTVPA are placed in Tier One. Those that do not meet the act's minimum standards, but are considered by the United States to be making significant efforts to bring themselves into compliance, are ranked at Tier Two. In Tier Three, we find those countries whose governments have yet to make compelling efforts to align themselves with the stipulations in VTVPA and therefore face the threat of sanctions by the United States. ${ }^{11}$ Human trafficking is not the only crime by which the US ranks other countries. In fact, this tool of foreign policy is used to rate how other governments have addressed the problem of drug trafficking (Friman 2010:96). However, as Kay Warren notes, TIP's ranking system is notable in its effect of shaming other societies (Warren 2010, see also Friman 2010:92). In fact through TIP rankings, the "stick" approach of sanctions need not even be exercised, as long as the "threat" is made through published comparisons with exemplary states. Interestingly, the United States itself was not included in the TIP Report rankings until 2010, a full 9 years since the system was created. Clearly through the TIP Report's rankings is a strategy on the part of the US government to manage and shape the criminal justice landscapes of transitional states.

\section{Making a narrative "Master": technologies of emotion and logic}

Scholars in a number of disciplines have used the term "master narrative" to describe a range of normative conceptualizations and sociopolitical phenomena, such as dominant environmental discourses (Harper 2001), historically based gender and power relations (Erler 2003), media characterizations of military interventions (Hackett and Zhao 1994), teacher sex scandals and pedophilia (Cavanagh 2008), and broad intellectual revolutions, like "the Enlightenment" (Gikandi 2001). ${ }^{12}$ All of these approaches conceptualize master narrative as a Lyotardian concept: a preexisting form of interpretation which is socioculturally reproduced and thus normalized (Lyotard 1984, Bamberg 2003). ${ }^{13}$ A master narrative is directed from and ultimately constructed and reproduced as social reality by dominant institutions, agents and systems. While "master narratives" have been described as frames from within which oppositions to dominant structures and power formations often

\footnotetext{
${ }^{11}$ Tier Three states could also, the Act reads, face US opposition to assistance from international financial institutions such as the IMF and the World Bank (Public Law 2000:21).

12 A recent symposium at Brooklyn Law School was titled "Writing the Master Narrative for U.S. Health Policy"(Brooklyn Law School 2012).

${ }^{13}$ Lyotard's concept of "meta-narrative" is an idea, now standard in post-structural theory that, along with Foucault (1972) notion of episteme, suggests that the norms are interpretive symbolizations of cultural forms.
} 
emerge, here I want to use the case of human trafficking to explore and to tease apart the characteristics and components of the master narrative as a genre (Bakhtin 1986) and to consider how the dominant narrative is "taken up" in popular culture and to compare it with data that do not fit into its framework. The term "uptake" originally comes from speech act theory and it refers to the perlocutionary force, or the effect an utterance has on an interlocutor in face-to-face conversation (Schegloff 1982). "Uptake" is also used in the area of language acquisition to describe the retrieval of information already acquired by learners. Roberts and Sarangi (2003) expand the analytical power of the term to include the understanding of a particular linguistic concept and its use in professional practice. I further expand the meaning to suggest that "uptake" is not only an acknowledgment or understanding of a discourse but also in the case of a dominant discourse, its adoption or appropriation as a standard mode of communication, knowledge and practice. A basic feature of a master narrative is that while there may be an initial single author responsible for its creation, this original source becomes irrelevant as it is pushed forward, institutionalized and "read" by others. Take, for example, the policy of containment, the blueprint for the US relationship with the Soviet Union after Second World War that emerged from the Moscow diplomat George Kennan's analytically insightful "long telegram." What began as a diplomatic strategy, which initially cautioned that the United States distinguishes carefully between Russian culture and Soviet power in formulating foreign policy, ushered in a culture of Cold War paranoia, practices and international conflicts which went far beyond the author's initial ideas. $^{14}$

Put another way, the components of the master narrative and its discursive technologies that reproduce it play crucial roles in its representation and dissemination, making it "master" over alternative individual or collective perspectives or accounts. ${ }^{15}$ For example, most of the technologies of the antitrafficking narrative blend emotion, authority and reason in the act of representation. On the one hand, the narrative must attract attention, gain a spotlight and to do this, usually as an introductory process, it attempts to elicit spontaneous feelings from recipients: intrigue, alarm and outrage. The estimated staggering figures of human trafficking victims suggest a far-reaching crisis and epidemic of exploitation, particularly of a crime that is not committed as an explicit act of violence. ${ }^{16}$ At the same time, authority and logic provide the frame through which information gets

\footnotetext{
${ }^{14}$ Kennan's analytical telegram was fleshed out further in an anonymous Foreign Affairs article and "came as close to authoring the diplomatic doctrine of his era as any diplomat in our history" (Gaddis 2011:249).

15 Somewhat parallel to this idea is Michael Warner's work on publics and counter publics, with the latter being much more subordinate, in fact subaltern, and thus perhaps uninterpretable (Warner 2005).

16 Scholars and practitioners working with gender violence and on other kinds of interpersonal violence might say that there is evidence of underreporting these types of abuse and exploitation. My own work in Kazakhstan among Muslim women activists, for example, found that some women were quite reluctant to report domestic violence to law enforcement (Snajdr 2005, 2007). At the same time, demographers, health officials and criminologists might note how relatively small the estimates of human trafficking victims are compared to cases of domestic violence (1.3 million in the United States-National Coalition Against Domestic Violence) or to public health problems such as type 2 diabetes (25.8 million Americans-U.S. Department of Health and Human Services 2011).
} 
read as official documentation. In order for it to appeal to its recipients' ideas of reason, master narratives must be built up from an accepted source of expert information. In a move to indicate systematic and cumulative research, the State Department has revised its TIP report over the course of several years. The act of revision suggests that logic and reason are at work in the process of defining the problem. In 2002, for example, the estimate was 4 million victims globally. The 2003 report included an estimate of between 700,000 and 900,000. The 2004 report states "between 600,000 and 800,000 are trafficked annually." In the same report, the estimate for the United States also fell from 50,000 (in 2002) to 17,000 annually. Both UNESCO and the US Government Accounting Office have criticized the official numbers and called for better data gathering in support of the idea that the crime of trafficking can be accurately calculated (GAO 2006). ${ }^{17}$ Revision and further research suggest credibility, self-reflection, a need to be precise and a drive to get it right. At the same time, however, the newer figures provided in the TIP report continue to appeal to emotion and alarm. From 2005 to the present year, no definitive annual numbers for human trafficking are given in the TIP report. Instead, previous estimates of sexual slavery are conflated with an estimate of global "forced labor" reported by the International Labor Organization (ILO) the UN Agency charged with addressing labor standards. This number is 12.3 million persons, including people enslaved in sexual servitude (TIP 2005:7). Staggering estimates are a powerful tool of master narrative construction, so rather than tamping down the number of persons trafficked as sex slaves, the government prefers to conflate them with victims of labor exploitation, drawn from yet another authoritative source (Fiengold 2010:20). ${ }^{18}$

Another tool of the master narrative that simultaneously combines emotiveness with reason and logic is the map. Maps carry explicit discursive authority in Western culture and provide definitive representation of political and cultural space (Harley 1988). Maps of human trafficking routes and cases have been published by NGOs, the US government and international organizations. Maps illustrating human trafficking usually portray the victim's countries of origin, the countries that serve as the corridors through which traffickers move people, and the final destinations where women are ultimately sold and held in bondage. For example, Fig. 1 shows a map from the Protection Project created in 2002 that depicts trafficking routes originating in Russia. The image includes forty-seven black lines each representing a documented instance of trafficking. The mapping of these routes invokes Wallerstein's (1974) world systems model where receiving countries mirror dominant core states, such as the United States or Western Europe. The periphery contains both origin and transit countries, and corresponds more or less to the

\footnotetext{
${ }^{17}$ UNESCO has set up a website (http://www.unescobkk.org/index.phpid.=1022) called the Trafficking Statistics Project to solicit more accurate figures. All of the papers at a 2003 U.N. Crime Commission conference noted that existing numbers were imprecise, totals ranged widely and there were serious gaps between known cases and proposed frequencies. For example, of the 50,000 people presumably trafficked into the United States annually, only 38 cases were actually documented in 1999. In Europe, numbers projected into the thousands for the Netherlands and Belgium yielded only 200 verifiable cases.

18 This same sort of alarming estimations are used in the case of child victims of armed conflict (see Greenhill 2010).
} 


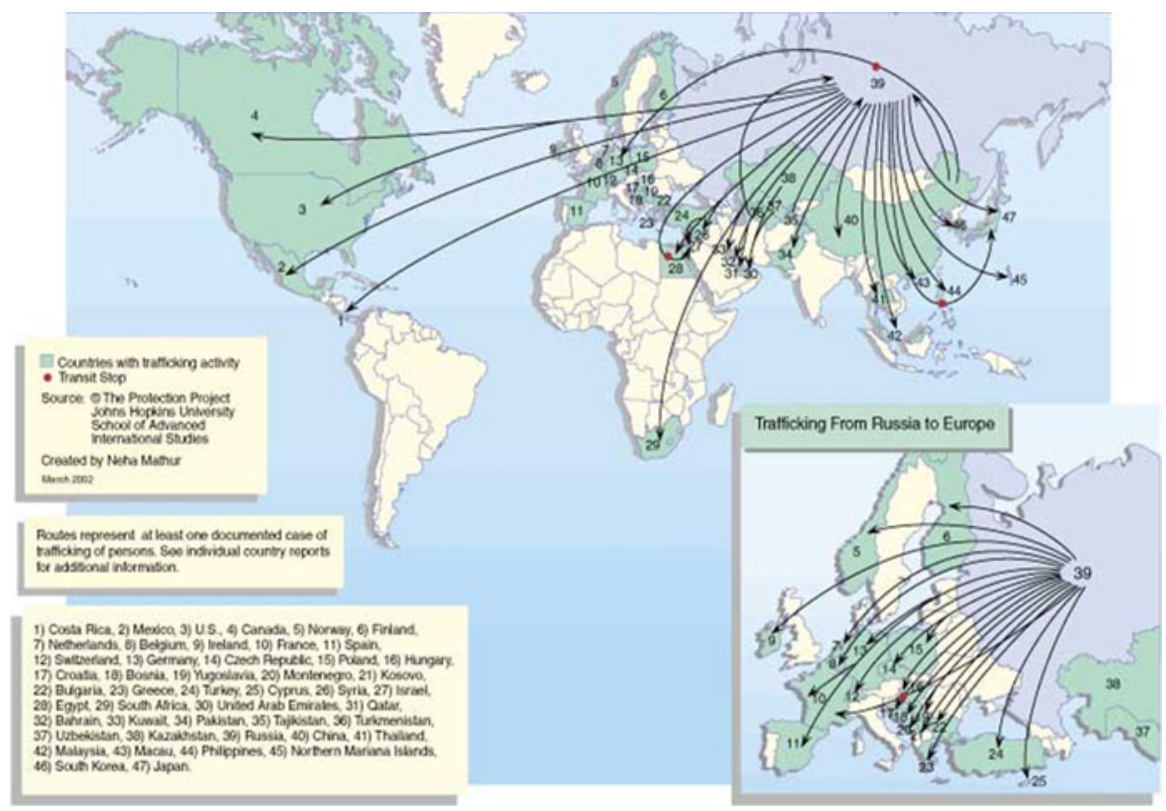

Fig. 1 Trafficking of persons, especially women and children: Russia routes. Source: Protection project

developing world or the former Soviet bloc. In the routes marked on these maps, we also see an overemphasis on supply and almost no representation of demand. In one map from the Protection Project, it appears at first glance that the United States is literally under attack from the women and children of the former Soviet Union and the developing world (Fig. 2). But this map also conjures up a threat of pollution and defilement, or humans as matter out of place (Douglas 1969), not necessarily assaulting the nation, but infecting it by the scourge of trafficking.

The official documentation on human trafficking evidenced through numbers and maps is further bolstered by the raw emotional power of visual images of both trafficked women and their callous traffickers in film. Films such as Bought and Sold, Frontline's 2005 documentary on global sex trafficking and other documentaries of the trafficking problem are vital tools with which anti-trafficking community defines and disseminates the dominant narrative. Bought and Sold, for example, combines brief and grainy footage of interviews with trafficked women, in some cases, matter-of-factly describing their situations with sub-titling akin to what one would find in police training films. ${ }^{19}$ For instance, the sub-title "Evidence" flashes on the screen to frame the extent of the problem and the mechanics of traffickers' criminal behavior. Frontline's 2005 documentary likewise provides the voice of an omniscient narrator, the same voice used in other films on serious topics

\footnotetext{
19 This film was made in 1997 and was funded by the Open Society Institute, a non-government organization founded and funded by George Soros.
} 


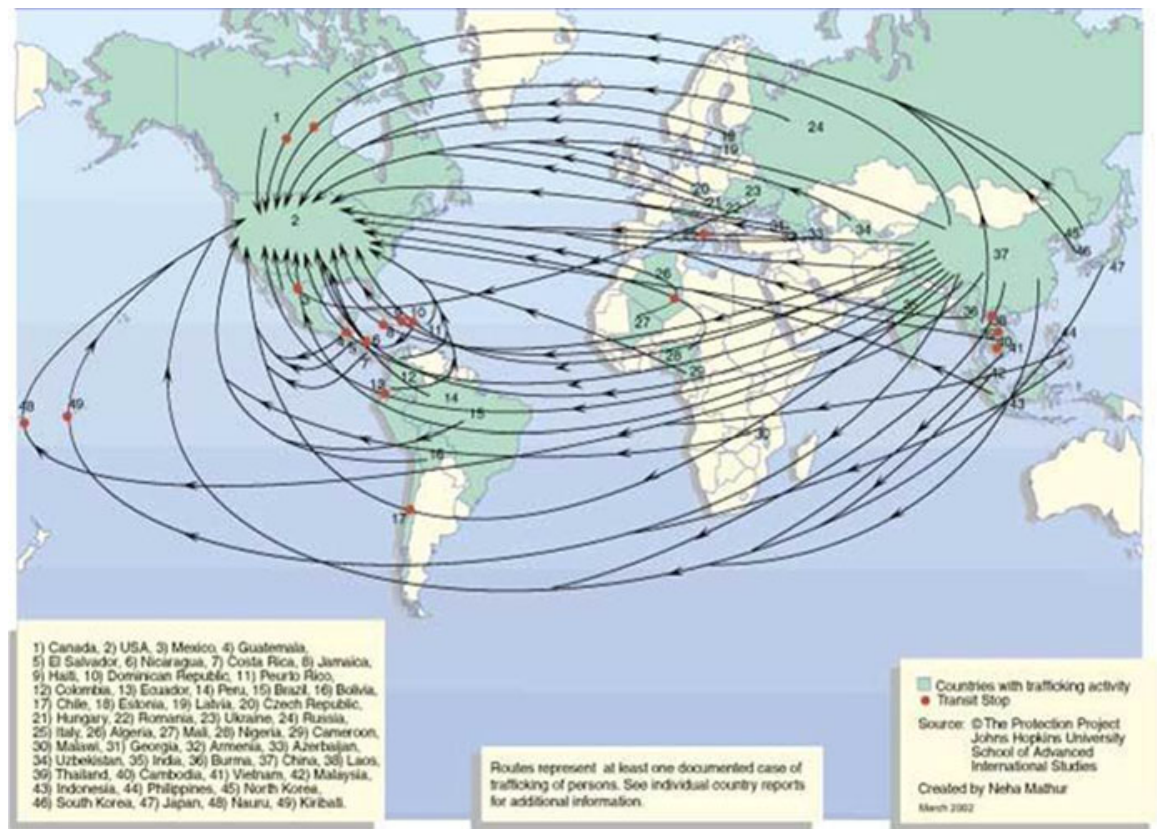

Fig. 2 Trafficking of persons, especially women and children: US routes. Source: Protection project

such as The Iraq War or Prescription Drugs, to describe suspenseful undercover footage. ${ }^{20}$

\section{Selective representations}

While maps, data and images convey human trafficking via a comprehensive, diverse spectrum of discursive technology that is both alarming and convincing, the master narrative delimits the content of these representations. Thus, it is important to consider not only the range of information that the dominant discourse contains, but also what kind of information it leaves out. For example, anti-trafficking accounts of victims almost always include simple binaristic themes and easily interpretable symbols of morality and immorality, murky, malevolent characters, and unsuspecting and ultimately helpless protagonists. Deviations from the ideal or the prototypical victims of trafficking are rarely depicted in official discourse and are usually well within an expected range of variation within culture. ${ }^{21}$ Moreover,

\footnotetext{
${ }^{20}$ Another documentary using undercover filming focuses on Roma child prostitutes allegedly "pimped out" by their relatives. The Romanian filmmaker dramatically attempts to "buy" the services of young boys in the back-alleys of Bucharest, but prior to any actual "sale" the traffickers get spooked and run off with money.

21 The anti-trafficking community often frames women involved in trafficking as helpless victims while some critics of anti-trafficking ideologies present the contrasting figure, also incredibly facile, of the happy hooker and the empowered prostitute. See Weitzer's (2007) critique of human trafficking crusaders. Both are problematic representations of individuals involved in sex work.
} 
these categories discourage complex analyses and complicated understandings of situational contexts and intersectional identities. Note the following narrative from the Protection Project:

Nasreen was a Tajik girl who worked in Moscow. Her boss asked her to become his mistress, promising money, housing, a car and a better life. Nasreen agreed to this arrangement. One day, a houseguest offered Nasreen the opportunity to work in Turkey. Nasreen's boss pressured her to accept the offer. Nasreen was tricked and trafficked to Israel for forced prostitution. With the help of a sympathetic journalist, Nasreen was able to escape and return home.

These easy-to-read representations, like number estimates and images, draw on both emotion and logic and discourage readers from focusing on what is not there. For example, in most of the narratives of human trafficking victimization, as in Nasreen's story above, there are very few concrete details. There is even less context and almost no background regarding the broader arena in which the terrible events described in the narrative take place. In another narrative from the 2004 TIP Report, we learn that Katya from the Czech Republic "followed the advice of a "friend"" who told her that "she could make good money as a waitress (TIP 2004: PAGE)." She ended up in an Amsterdam brothel, and "after years of threats and forced prostitution...was rescued by a friendly cab driver" (TIP 2004).

These limited stories are oddly similar to what Brunvand (1989) notices in urban legends or modern-day myths. ${ }^{22}$ The accounts are rarely longer than one or two short paragraphs. There are few details of place, time and general social milieu. Beyond the basic mechanics of the abduction, there is only a vague mention of the location of origin and final destination. Also, usually included but vague and unspecified is a supportive NGO. In a similarly brief and undetailed narrative from the 2009 TIP Report, an NGO is critical to the story but not identified or explained:

Azade, 22, left rural Azerbaijan to work at a massage parlor in Baku. But the massage parlor was a cover for a brothel. Soon after she arrived, a client who worked for the brothel owner forced himself on Azade and threatened to show a videotape of the assault to her father unless she engaged in prostitution at the brothel. Fearing the social stigma attached to rape and the consequences of bringing shame to her family, Azade submitted to several months of forced prostitution before she escaped with the help of an anti-trafficking NGO. (TIP 2009: Emphasis added).

Discourse analysts recognize how language is not a transparent rendering of life as it happens but rather constitutive of social reality in which we find ourselves. Narrative analysts (Norrick 2000; Trinch 2003) show how stories are used to do something. In other words, there is often a pragmatic purpose to storytelling. The US State Department explains at the beginning of the TIP Report's victim narrative sections that "victims' testimonies...illustrate the many forms of trafficking and the

\footnotetext{
${ }^{22}$ Montgomery (2011) has noted the role of rumor in reports of child trafficking cases following natural disasters in Asia, the Pacific and the Caribbean. A similar concern has been raised by Campion Vincent (2001) about the role of rumor in the problem of organ theft and trafficking. She argues that in ScheperHughes (2001a) with organ trafficking in Brazil her data conflate ethnographic stories of organ stealing and actual cases of organ selling. Nevertheless, Scheper Hughes is willing to consider both legends and reports as a set of practices (Scheper-Hughes 2001b).
} 
wide variety of places in which trafficking occurs" (TIP 2008:4). ${ }^{23}$ While it is understandable that victim identities would be disguised and that actual locations would be obscured in order to protect people who have been exploited and who may continue to experience danger, threats and intimidation, there is at the same time almost no cultural or contextual information that distinguishes the abuse or gives a sense of the experience of exploitation, subjugation or survival. Instead, we find only the abuse or violence perpetrated against them, and then quite abruptly it stops at "moments of rescue" or when "prosecutions are made." There is in fact very little that is "human" in official narratives of human trafficking, which amount to "thin description." ${ }^{24}$ Moreover, a curious feature of the victim narratives is that they are not "told by" victims themselves. Rather, the accounts that circulate that "establish" the crime are told by others. And these tellings are not legal testimony or testimonials told in the first person by the victim-eyewitness (see for example Beverly 1993:97, Trinch 2010). All the TIP victim narratives are written in the third person and begin with the victim's name, as opposed to in the first person when a woman would introduce herself as a person victimized: "My name is Rigoberta Menchu..." (Menchu 2010:1). Aside from the sentences that introduce the account, there is no mention of how accounts were elicited or who initiated the telling (Trinch 2003, 2010). Media accounts of victim's stories also tend to rely not on victim narratives, but information from second-hand sources. In a survey of press coverage on trafficking, Gulati notes that very little, if any, of the information reported comes from victims or from traffickers themselves (Gulati n.d.:16-17). ${ }^{25}$ Similarly, in Junger's iconic story (Junger 2002:165-166), as well as Jonathan Landesman's New York Times expose on the trafficking scourge in the United States (Landesman 2004:36), it is notable that for much of these reports, both the journalists and the experts are the ones who mainly speak on behalf of victims.

One could ask then not what one misses from a lack of details, but rather what one discursively gains from it. In this case, it seems that official trafficking narratives are not really meant to show anything else but the fact that victims can be and want to be saved. These narratives are not created as records to define trafficking or even to witness it. And they are definitely not created to show the complexity, diversity or variety of human trafficking that exists. These victim narratives are created to be taken up as a call for intervention. Arguably, by entextualizing these narratives within the official, NGO- or government-sponsored training materials, they gain a particular formal status and authority and their structure becomes naturalized as a "standard" story of human trafficking (cf. Trinch 2003), imbuing the government-sponsored training with an authority it might otherwise not have. They become official tools of authoritative discourse and of information dissemination on a global scale. For instance, a curriculum for human

\footnotetext{
23 This statement explaining the inclusion of "victim narratives" first appears in the 2008 TIP Report and in all subsequent reports.

24 I borrow this term from Robert Hayden (2008) who coined it in a response to Dawson (2008).

25 According to Gulati (n.d.), most stories on human trafficking between 2000 and 2005 rely on government or official sources or on sources from organizations receiving government support (43\% from government, $23 \%$ from law enforcement agencies and $19 \%$ from NGOs combatting trafficking or providing services to victims).
} 
trafficking training developed and published by the GAATW includes the same type of third-person narrative that is devoid of much of the humanizing details that are common elements of narratives of violence and exploitation, but instead trafficking narratives always frame the victim as innocent, and the trafficker as "evil" in facile ways. $^{26}$

\section{The master narrative unbound: self-fulfilling retellings}

If the concept of uptake can help to explain the curious limitations and legend-like structures of victim stories in TIP reports, it may also be useful to consider how media and other conveyors of communication have appropriated and adopted the dominant discourse beyond the scope of official accounts, in other words, how these technologies come to be part of what Warner (2005) calls "the public." In the news and in popular culture, we see that the master narrative gets told and retold by other interlocutors. How it gets retold and by whom has implications for its dissemination, appearance and utility. For instance, in terms of media, Gulati (no date) argues that while print media coverage of human trafficking has increased as the efforts of government and NGOs have stepped up, what gets reported has really been mostly a reflection of the "official" perspective. Gulati has found that newspaper and magazine journalists "have done a poor job of representing the various viewpoints on the issue" (Gulati p. 22), a situation which he blames on the culture of journalism where reporters simply rely on a canon of the presumably credible sources and on the general difficulty of reporting on underground behavior. For example, Landesman's (2004) New York Times Magazine feature on the trafficking scourge in North America quotes outdated estimates of 50,000 victims in the United States each year. ${ }^{27}$ Even in cases of non-mainstream print journalism, the persistence of older versions of the master discourse is surprising. For example, responding to a reader's question about White Slavery in 1999, Straight Dope columnist, professional myth buster and proponent of factual accuracy Cecil Adams echoed Doezema's critical and informed analysis about past moral panics in his syndicated column in the Chicago Reader, but then included an update in 2002 from a reader who noted that:

\footnotetext{
26 The narrative reads: "Delia, from a small village in Southern Romania, was offered a short-term contract for a job in a flower shop in Germany by a friend, Matache. Matache promised to organize everything: passports, visas, and employment contract. Delia would earn 100 Deutsche marks per day, and be free to come home whenever she wanted. However, when they arrived in Germany, Matache gave her passport to a man who met them in exchange for some money. Delia realized what was happening, but when she tried to move away a gun was pulled on her. She was taken to a house and locked inside. When Delia tried to resist, she was raped and beaten by two men. For some time, they forced Delia to have sex with several men per day, and forced her to use drugs. There were other women working in the house but they were not allowed to communicate with each other. All the women were forced to take contraceptive pills, and anyone who got pregnant was forced to have an abortion (Handbook 1999, GAATW:10).

27 A report on trafficking in Florida published and circulated in 2005 by the FSU Center for the Advancement of Human Rights also cites the 50,000 estimate even though officials had dropped the estimated number of trafficked persons into the United States as 17,000.
} 
While... "white slavery" may not have been a big deal in the $19^{\text {th }}$ century for young European women and girls, the problem of human trafficking is an unfortunate $20^{\text {th }}$ century reality... [and] is one of the fastest growing areas of international criminal activity and one that is of increasing concern to the U.S.

Administration, Congress and the international community (Adams 2002).

The reader includes an outdated official estimate of 1-2 million annual victims and provides Adams with URL links to the US State Department. Adams then innocently replies: "I knew about slavery in Asia but frankly wasn't aware of how widespread the problem was. Thanks for bringing us up to date" (Adams 2002). At the same time, print media formats can recast complex information in order to conform to the simple messages of the grand discourse. For instance, Donna Hughes, a professor at the University of Rhode Island, reported in 2006 on the growing problem of prostitution in Iran, a country currently at the rank of Tier 3 in the TIP Report. While her article covers a range of issues from street hookers to domestic abuse, the piece is framed by the headline "Iran's Sex Slaves Suffer Hideously under Mullahs" and thus the obfuscating message of an over-simplified equation that Islamic leadership results in female slavery.

In contrast to print journalism, television and documentary films on human trafficking have aggressively tried to capture the "underground experience" and to find the emotional story of a victim's experience. But, like the narratives in the TIP Reports, one sees attempts to portray iconic victim stories, long on dramatic tension and short on contextual detail. Moreover, in television expose's such as CBS' Peter Van Sant rescuing sex slaves in Romania (2009), or NBC's Chris Hanson saving child prostitutes in Cambodia (2005), the story is about the heroic journalist responding to the horror of the crime up close, but rarely does one see traffickers or speak with police about the difficulties evident in responding to the crime. Even the representation of victims in documentary film has become means to maintain interest in combatting the crime, a sort of self-fulfilling representation to attract donors and public support. Lindquist (2010) argues that Indonesian NGOs "are dependent on the enduring public interest in trafficking" and "the testimonial of the victim becomes a necessity in the formation of an aesthetic of trafficking (Lindquist 2010:233)." This "audit culture" of the image of the victim, according to Lindquist, is a sort of self-fulfilling enterprise, which actually encourages the production of the documentary medium and thus of one form of the master narrative itself.

In addition to being "taken up" by mainstream media (Farrell and Fahy 2009), the master narrative has also entered the realm of pop culture, where it continues to be reproduced and reinterpreted in new but authoritative ways. For example, several episodes of the television cop drama Law and Order have incorporated human trafficking as a main plot device. The feature film Taken, produced in 2008, centers on the kidnapping and selling into sexual slavery of the protagonist's daughter while on a trip to Paris, has spawned a 2012 sequel, Taken $2{ }^{28}$ While these fictional accounts take liberties with official accounts, recently published novels about sexual

\footnotetext{
${ }^{28}$ Taken grossed \$226,830,000 worldwide according to boxofficemojo.com. The Whistleblower, a film released in 2010 dealing with human trafficking in Bosnia, a subject that is discussed later in this article, and which is based on true events, grossed $\$ 1,124,000$ according to the same source.
} 
slavery dedicate the inspiration for the work to real-life (but un-named) victims of trafficking and make explicit reference to government sources in order to educate their readers about facts (Hodge 2011; Nelson 2011). ${ }^{29}$

The dominant trafficking discourse is not just retold in media and popular culture, but also recast back into the sphere of official government policy agendas such as border security and the US's relationship with so-called rogue states. For example, in a 2004 Florida speech on human trafficking, George Bush accused the Castro regime of supporting child sex trafficking and sex tourism. To support his claim, Bush cited a two-page report published by the Protection Project, the Johns Hopkins anti-trafficking NGO. Yet neither of the two sources included in this report explicitly identified a single reported case of trafficking in Cuba. In fact, the Protection Project's report only suggested the possibility that sex tourism, not sex trafficking, in Cuba might be "on the rise." Regardless of the controversial issues involved in comparing sex trafficking with sex tourism, Bush accomplished the dual aims of promoting the issue of human trafficking and reinforcing the US isolation and vilification of Castro's Cuba, maligning both the dictator and the country through its alleged association with the exploitation of women and children. ${ }^{30}$ Interestingly, there is not one documented case of trafficking originating from, passing through or ending up in Cuba. ${ }^{31}$ If we return to the Protection Project's map, we see verified cases coming from the Dominican Republic (a Tier 2 country), but not one line links Cuba. ${ }^{32}$

It is no surprise, then, to find that the US government rates Cuba's status as a non-compliant Tier 3 country in the various versions of the TIP Report. Other Tier 3 countries in the 2004 report include Bangladesh, Burma (Myanmar), Sudan, North Korea, Sierra Leone, Sudan and Venezuela. These states are mostly countries and governments with which the United States has ideological conflicts that go far

\footnotetext{
${ }^{29}$ Sibel Hodge, for example, author of "Trafficked: The Diary of a Sex Slave" writes "I normally write chick lit books... About five years ago I watched a mini-series about girls from Eastern Europe who'd been trafficked. It haunted me for a long time.... Then a little while ago I was sitting in a doctor's surgery waiting for an appointment and picked up a magazine. Inside was a story about one woman who had been trafficked. It made a chill run through me, and I realized that in those five years, I'd never heard anything in the media about it. That got me thinking, and I started researching other victim's stories online. They were horrific... In 2007 the US Department of State carried out a Trafficking in Persons report. The statistics shocked me to the core:700,000-800,000 men, women and children trafficked across international borders each year, approximately $80 \%$ of which are women and girls, and up to $50 \%$ are minors. The figures will be a lot higher four years on..." (Hodge 2011:iii).

30 See Montgomery (2001) for a case study on the ethnographic realities of sex tourism in Thailand.

31 The 2001 TIP Report notes "isolated cases of trafficking [into Costa Rica] have involved persons from Africa ... Cuba ... and the Middle East” (TIP 2001:38). No details are given. The 2003 TIP report does not even include Cuba in its country rankings although it describes Cuba in its country report as a place for sex tourism, agricultural labor and construction work (the latter linked to political dissidence). TIP 2004-2010 lists Cuba as a Tier 3 country but the 2006 TIP Report states that "the nature and extent of trafficking in the country is hard to gauge due to the closed nature of the government and a lack of nongovernmental reporting" (TIP 2006:102). TIP 2011 adds that trafficking in Cuba is "particularly difficult to gauge".

32 Also not reported in Bush's speech was the Protection Project's report's finding that American's started the sex tourist business in Cuba in the 1950s. The report also noted that the current users of the sex tourist industry in Cuba are American and Canadians, which Bush did mention, but instead placed Canadians first in his remarks.
} 
beyond the exploitation of women and children. Perhaps realizing the political ideology behind the TIP rankings, organizations such as Human Rights Watch and Amnesty International have criticized these rankings, arguing, for example, that, based on actual known cases of trafficking, countries such as Macedonia, which enjoy Tier 1 status, should really be placed in Tier 3. Nevertheless, whether it serves to shame developed countries to meet US demands to reform legal codes (Warren 2010) or as additional fodder for applying discursive pressure to rogue states, the ranking system endures as a fundamental part of the master narrative.

In the two ethnographic cases that follow, I examine how the master narrative fails to take up important details about local situations of human trafficking in its own discourse and disregards local perspectives on human trafficking that run counter to conventional anti-trafficking views. In the first case, from Bosnia, which has arguably moved beyond the US-led faith-based and feminist "rescue industry" paradigm characterized by critics as dominating the landscape of international intervention (Agustin 2007, Bernstein 2010) one finds a story of compliance and success but also a case of simplified representations that ultimately disregards the role of the United States in contributing to the problem. In the second case, from Kazakhstan, the picture is more one-sided and even somewhat confrontational on the part of local-level responses to the anti-trafficking narrative.

\section{Bosnia: aftermath of a perfect storm}

The Bosnian police captain leaned toward me, shoulders squared and arms folded as he recounted his work in Tuzla Canton. "We had a case where some Americans were involved with a girl from a nightclub and when the military police began their investigation these individuals were immediately repatriated to their country" he said, with his brows furrowed. He went on, leaning backwards in his chair "The IPTF [International Police Task Force] had a rotation every 6 months. So all of them moved and we never got any feedback. We also couldn't accuse or bring to trial any of these local people because we did not have witnesses from the Americans." The officer was referring to the specific context of the post-war situation in Bosnia and Herzegovina which witnessed the trafficking of hundreds of women from the former Soviet Union for the purposes of sexual exploitation (Limanowska 2002). Bosnia, in effect, amounted to a "perfect storm" of porous borders, a dysfunctional criminal justice system, several neighboring states such as Moldova and Ukraine with emaciated economies, a population of international peacekeeping forces, including international law enforcement, and, most importantly, a relatively large contingent of private civilian contractors. ${ }^{33}$ Unlike regular military in SFOR, these Americans lived among local civilians and led unmonitored private lives without the same kind of oversight as SFOR personnel and had money and resources. One American contractor reportedly told a colleague that they considered Bosnia to be an "adult playground" (Mendelson 2005:35).

\footnotetext{
33 Between 1995 and 2003, 28,000 US soldiers and American private contractors had been stationed in Bosnia (AE 2003:24). The total amount of US personnel in Bosnia declined steadily after 1998 and amounted to around 2,500 by 2003 .
} 
The link between the proliferation of sites of prostitution and black markets and the presence of international peacekeepers is well-known (Andreas 2008). In Bosnia, the troubling link between the specific type of peacekeeping and reconstruction environment and the proliferation of human trafficking was initially uncovered by Martina Vandenberg, a lawyer working for Human Rights Watch. In her report to Human Rights Watch, Vandenberg found that not only were local police and other officials involved with human trafficking, but members of the International Police Force (IPTF), including Americans, were frequently identified as clients of traffickers and who purchased women in bondage. ${ }^{34}$ More troubling was the instances in which employees of the US contractor DynCorp allegedly purchased women as sex slaves. Vandenberg learned that these private contractors and international law enforcement agents operated with impunity, and once accused of wrong-doing, were quickly repatriated to their home country or transferred to other sites in the Balkans. One police officer from Zivinice outside of Tuzla complained that these foreign individuals presented the "biggest problem for us. We can't do anything against them-they are above the law" (Vandenberg 2002:64). In a 2005 report commissioned by the Center for Strategic and International Studies, Sarah Mendelson investigated the specific conditions encouraging the complicity of a system of peacekeepers with respect to the exploitation of women in the Balkans, including Bosnia and, more recently, Kosovo. For instance, she found that US military leadership in many cases tolerated prostitution services provided to troops and that some of these patrons were aware of the exploited status of the women involved (Mendelson 2005:33). Both Vandenberg's and Mendelson's research are examples of the important complexities of the links between post-conflict zones and human trafficking for sexual exploitation.

My own visit to Bosnia in 2006 with Jacqueline Berman and Vandenberg to investigate the aftermath of this confluence of conflict, neglect and complacency not only confirmed the correlation of the presence of peacekeepers and the problem of trafficking but also reiterated evidence that the situation had substantially changed. But how it had changed was a matter of debate. For example, it was clear from interviews with police in Sarajevo and in Tuzla that human trafficking had been both a "real" problem and a "serious" one. But it was equally clear from speaking with law enforcement officials and some staffers from international organizations that trafficking was a crisis that had passed. For instance, the deputy police commissioner in Tuzla told me that after the war ended in 1995, there was a significant problem with trafficking around the town, but that since 2003, there had been no cases reported. In between that, time was a coordinated effort to shut down a string of brothels lining the roads on the outskirts of Tuzla near Eagle Base and in other districts such as Zivinice. ${ }^{35}$ Local police observed that in place of human

\footnotetext{
34 One case in particular, known as the Prijedor case, involved dozens of women claiming to be victims of trafficking and allegedly directly exploited by IPTF officers (Vandenberg 2002:49).

35 On 2 March, local police in seven cities in the MND(N) Area of Operations (AO) participated in a nationwide crackdown on human trafficking as they raided brothels and detained those suspected of engaging in this activity. Although "International Police Task Force (IPTF) assets were made available to them, the local police were responsible for conducting this significant, coordinated police action. Designated $\mathrm{MND}(\mathrm{N})$ personnel and facilities were prepared to provide temporary support for the women but the need for lodging and care at these locations proved to be unnecessary" (AE 2003:53).
} 
trafficking, there were serious problems with resettlement, theft of property and illegal drug trafficking.

Speaking with police and NGOs also revealed widely divergent stories about the present. While the police kept insisting that the crisis of human trafficking was over in Bosnia, NGOs suggested that trafficking was going underground, moving out of the brothel and dance club and into the labyrinth of private homes in nearby towns. ${ }^{36}$ When I reported this theory to the Tuzla police officers, one captain responded wryly that "they [NGOs] would not exist without the problem." His reply echoed the conundrum of trying to confirm a hidden crime about which Weitzer (2012) and other critics of the anti-trafficking community have complained (Fiengold 2010, Warren 2010). Additionally, Limanowska reports for Bosnia that in "many cases it is not possible to find out whether women being assisted by NGOs are cases of trafficking, violence against women, forced prostitution or exploitation of prostitution more generally" (Limanowska 2007:77). Wedel (2001) has noted the lop-sided relationship between non-governmental organizations in Eastern Europe whereby foreign donor governments and organizations drive the issues and essentially set the standards and back up these themes with funding. In fact, she noted that a study of NGOs receiving foreign funding in the region "found that 'local groups proliferated... around issues that Western donors found important, but rarely around issues that locals confronted on a daily basis"' (Wedel 2001). ${ }^{37}$ To complicate even further Bosnia's case of what Berman (2008) describes as postconflict conflict, two staffers from an international NGO revealed to me that despite what local police think about women's groups chasing money, the lion's share of the resources to combat human trafficking was mostly controlled by only one organization, the International Office of Migration. They also noted that IOM received most of its counter-trafficking resources from the US government via USAID. Since funds came through IOM, they argued, local NGOs had little if any input into how the problem could be handled or how victims could be assisted (Berman 2008).

Since 2010, Bosnia has been ranked by the United States at Tier One. Yet looking at how the official story of Bosnia has been "taken up" by the United States reveals interesting discrepancies that perhaps only a close reading can yield. For example, following Vandenberg's 2002 report, the 2003 TIP country narrative for Bosnia states: "although the presence of international civilian and military personnel has contributed to the trafficking problem in $\mathrm{BiH}$, the local population actively sustains it" (TIP 2003:36). Despite Vandenberg's data on private contractors, the TIP Report defines the problem as being a local one, not an outcome exacerbated by international relationships between assistance and mismanagement. Moreover, no mention is made of the type of "internationals" contributing to the trafficking industry (TIP 2003:36). The only other mention of peacekeepers in the 2003 TIP Report comes from brief passages about Sierra Leone and East Timor (TIP 2003:251). The 2004 report mentions a UN position paper

\footnotetext{
36 Mendelson (2005) and Dawson (2008) also report this shift to underground trafficking, but provide little evidence of this assertion.

37 Quoted from Sarah E. Mendelson and John K.Glenn 2000:19).
} 
setting a new code of conduct for peacekeepers (TIP 2004:12). ${ }^{38}$ The 2005 report included information on soldiers and sexual exploitation, noting training efforts on the part of the Department of Defense, which initiated a zero tolerance policy toward trafficking. On my visit to Bosnia, it was never clear what type of antitrafficking training soldiers were receiving nor were there materials available to examine other than the TIP report handed to me at the gate at Eagle Base. Following Mendelson's report on the Balkans, the 2006 TIP report included very basic action plans sketched out for NATO and OSCE, and by 2009, almost all country reports contained a concluding line about the implementation of "peacekeeping training" but with absolutely no details as to who was being trained, how many, or with what materials. Finally, while Bosnia appeared to fit perfectly into the master narrative according to various TIP reports, moving from struggling post-war chaos and lawlessness at Tier Three to legal discipline and NGO-run victim assistance at Tier One, there is no record of the shameful role of some US peacekeepers in the official TIP account.

\section{Kazakhstan: a non-compliant state}

The Central Asian Republic of Kazakhstan could not be further from Bosnia in terms of its position within the international community, its political trajectory following the collapse of communism and its experience with the problem of human trafficking. Wedged between Russia and China and in the vicinity of war-torn Afghanistan to its south, including Afghanistan, Kazakhstan has been politically stable under the leadership of Nazarbayev since its independence in 1991. Its ethnic diversity has not resulted in armed conflict (Schatz 2004), and its economy has been bolstered by an abundance of natural resources including the crucial Tengiz oil fields in its western region (Kramer 2010).

My work with the anti-trafficking movement in Kazakhstan originally occurred as part of a US State Department funded development project aimed at providing training for law enforcement on domestic violence. In 1999, the Bureau for International Narcotics and Law Enforcement Affairs (INL) had awarded Florida State University a two-year grant to work with local stakeholders to create, implement and evaluate a domestic violence training curriculum for police, prosecutors and judges. ${ }^{39}$ In 2001, when my colleague Dmitriy Vyortkin and I were awarded two additional years of funding, we were encouraged by INL staff to incorporate a human trafficking component into our training of police on gender and domestic violence. From the perspective of the State Department, Kazakhstan was an appropriate site for conducting an anti-trafficking training project: it was deemed a source, transit and receiving country. Moreover, it ranked Kazakhstan at Tier Three, along with states like Cuba and North Korea, in both the 2001 and 2002 TIP

\footnotetext{
38 This report also only mentions Morocco and East Timor as problem areas in which peacekeepers were clients of brothels where trafficked women were suspected.

39 The project trained dozens of officers, prosecutors and judges in several oblasts across the country (Snajdr and Vyortkin 2001).
} 
Reports. In March 2003, Vyortkin and I held a three-day workshop in Almaty that included Kazakhstani border police, city police, National Security Agency officers, and judges and prosecutors. To lead our effort, we invited a Florida State Prosecutor who had experience managing and training legal professionals to collaborate with women's NGOs who specialized in gender violence and women's rights, including the Feminist League, the Crisis Center Network and the Women's Information Center, an advocacy group for women in need of legal assistance. Our workshop also included the local coordinator from the International Organization for Migration (IOM), the main international NGO working on trafficking in Kazakhstan, a liaison from the American Bar Association-Central East European Law Initiative (ABA-CEELI), a US organization helping with legal reforms in postsocialist states and a staff member of the US Embassy in Almaty.

As we expected, the workshop showed us local perspectives on human trafficking in Kazakhstan, but it also uncovered how these views and experiences intersected with or significantly departed from the dominant discourse on the problem. As is common in the former Soviet Union, meetings and seminars usually began with formal introductions and lengthy speeches given by the superiors of key participants who eat up time only to disappear when the substantive work begins. In our workshop, however, many of these upper-level administrators stayed to participant in the group's attempts to define the problem of human trafficking in Kazakhstan. Here, local women's NGOs took the lead, referring to the UN Protocol on Human Trafficking and introducing material from international women's groups. But when Katarina, the local coordinator of IOM, announced that her organization estimated that over 5,000 people were trafficked out of Kazakhstan each year, police and prosecutors were at first stunned, and then curious. They asked her IOM came by this figure. She then admitted that there had only been 53 documented cases of trafficking in 2001, but explained that IOM calculates the estimate as a multiple of what actually gets reported. One officer then remarked that 53 cases seemed small when compared to other crime problems plaguing the country. ${ }^{40}$

In addition to confusion about estimates and actual cases, participants found it difficult to isolate the problem from the complicating aspects of Kazakhstan's postsocialist economic and political transition. A Border Patrol captain announced that his department had been watching several travel agencies in Almaty which they suspected of trapping women into situations of forced prostitution abroad. He admitted, however, that other border problems, such as illegal drugs, were given priority in his office. Moreover, his unit still had no evidence that these businesses operated as international organized crime networks nor did it have adequate resources to thoroughly investigate these companies. ${ }^{41}$ Besides, he added, "if they have all the documents then there is little chance that we can stop them" and he surmised that traffickers would need false documents only if they were to take

\footnotetext{
${ }^{40}$ The UN Crime Commission notes that over estimating is a general problem in assessing the scope of human trafficking. For example, annual estimates for the Netherlands is 1,000-3,000 but only 289 cases were documented for 1999. Similarly, Belgium's figures were estimated at 1,000-3,000 with only 270 documented cases (Makkai 2003).

${ }^{41}$ Zhang and Chin (2002) note that organized networks are not the mechanism of human smuggling in China. See also Schloenhardt (1999).
} 
under-aged women out of the country. Our US prosecutor concurred, casually observing that one could easily access counterfeit documents over the Internet. On hearing this, another officer laughed, noting that most Kazakh police units did not even have computers. Perhaps embarrassed at his colleague's admission of a lack of resources, another officer said "Look law enforcement in the post-Soviet period is working. People still shout 'help, police!'” But, he suggested, low pay and outdated training certainly undermined the effectiveness of police work. He then challenged the US trainer with the question: "How much do you make in America as a prosecutor?"

Elaborating on this theme of a struggling society, another officer complained that official newspapers did report anything on trafficking but that she had read a tabloid news story claiming that the most popular response to a survey of career aspirations among female teens in Northern Kazakhstan was "to become a hard currency prostitute." Another officer asked "How can you stop a woman from leaving a poor village to work the streets of Almaty?" One Kazakh prosecutor then concluded that "if a woman wants to do it, to travel abroad, it is difficult to call this exploitation. We call these people 'adventurers.'” NGO activists quickly challenged this theory as victim blaming and argued that traffickers were taking advantage of desperate youth. Nazpary (2001) describes this disturbing moral resignation exhibited by some workshop participants as a function of the dislocation and chaos of Kazakhstan's new but brutal market economy which has created a kind of postsocialist normalization of desperation. ${ }^{42}$ At the same time, how participants view vulnerability and thus construct a particular kind of moral exclusion (Opotow 1990) in this case may be exacerbated by ethnicity. Demographers and anthropologists studying migration have characterized post-Soviet out-migration as the result of the "push" factors of poor economic prospects which force people to seek work abroad (Craumer 1992; Korobkov and Zaionchkovsaia 2004), including in particular young women (Bloch 2003). The push of desperation is complemented by the "pull" of what are perceived to be more prosperous opportunities in Western countries (Hierman 2004). In Kazakhstan, the attractiveness of these pull factors have also depended significantly on one's ethnic identity. Thirty-seven percent of Kazakhstan's population is ethnic Russian. Though ethnic tensions between Russians and Kazakhs have not been violent, between the years 1994 and 2006, some 3 million Russians had left the country. In interviews I conducted with young Russians, many felt they had little or no job prospects and believed that ethnic Kazakhs and other Central Asians were being privileged over ethnic Russians in the new economy. Likewise, we learned from speaking to police that a majority of prostitutes in Almaty and other towns in Kazakhstan were ethnic Russians.

In addition to revealing a somewhat callous ethnovictimology, the workshop inspired open criticism of the actions of international NGOs in the country and the pressure to conform to a US version of "rule of law" in Kazakhstan's transition from socialism. For instance, officers also complained that IOM staffers drive around Almaty in their giant SUVs, looking no different from the new mafiya

\footnotetext{
$\overline{42}$ See also Shelley (1994) on the perception of change in crime frequency following the collapse of the Soviet Union.
} 
menacing post-Soviet society. Most people, including police, drive old Russianmade Ladas or Trabants. Some police units cram as many as four or five passengers in a patrol car in order to get to a crime scene or a police incident. One frustrated judge then asked "What about receiving countries? How is this possible that so many women end up in these foreign cities?" Another asked "How are we to punish them-even if we change our laws - if women end up outside of Kazakhstan?" A prosecutor then suggested the laws in receiving countries like the United States and in Western Europe were passive. A third judge criticized the United States for demanding changes in the law of a sovereign state and challenged the credibility of our US consultant by asking how many cases of trafficking she had actually prosecuted. $^{43}$

These questions certainly revealed the difficult position of states that were not on the receiving end of the trafficking phenomenon to define the problem of trafficking and to respond to it in terms of adjustments to the criminal justice system. They also revealed that our Kazakhstani stakeholders were not so much telling us about the problem of human trafficking in Kazakhstan, as they were being introduced to the version of human trafficking represented by the master narrative. Indeed the US prosecutor's training materials at our American-funded workshop were developed in 1999 by the Global Alliance Against Trafficking in Women, the international antitrafficking NGO. Likewise, the Crisis Center Network, as part of its "expertise" on human trafficking screened the film Bought and Sold, which the group's director had received from the international organization La Strada while attending a trafficking conference in Kiev. ${ }^{44}$

Nevertheless, the participants agreed to create a pamphlet for high school students regarding human trafficking and its dangers. ${ }^{45}$ As a measure to respond to trafficking, it certainly seemed to address "prevention," one of the three P's touted by the State Department as a critical response to human trafficking and outlined in the workshop by our US prosecutor. ${ }^{46}$ In terms of "protection" and "prosecution," these areas proved more difficult, but participants suggested that women's groups could provide shelter for victims and that Article 128 of the Kazakhstani criminal code could be used to prosecute trafficker. Additionally, an anti-trafficking bill was under debate in the majilis, Kazakhstan's parliament, and participants agreed to lobby for its passage.

We also learned that around the time of our Almaty workshop, Kazakhstan was being evaluated for the 2003 TIP Report, due out later that summer. The US

\footnotetext{
43 She replied that she had not prosecuted any cases. She replied "None, I am actually a trainer in the U.S. and I manage the prosecutor's office.

44 La Strada's Warsaw office was established in 1995 as "La Strada Program: Prevention of Traffic in Women in Central and Eastern Europe", under the supervision of Stichting tegen Vrouwenhandel (Dutch Foundation against Traffic in Women, STV). Eight years later, this program expanded to a network of 9 independent but coordinated groups in Poland, the Netherlands, Czech Republic, Ukraine, Bulgaria, Belarussia, Bosnia-Hercegovina, Macedonia and Moldova.

45 In addition to the pamphlet project, the workshop also brought down interagency barriers, introduced law enforcement to the work of NGOs and educated women's activists about the bureaucratic and legalistic constraints of policing (see Snajdr 2006).

46 While participants looked to the US consultant for guidance, she admitted that she was not aware of a US pamphlet that supported public awareness on human trafficking.
} 
Embassy staff in Kazakhstan would be submitting the information for this report. It was therefore encouraging to all of those involved in the workshop that a US Embassy representative attended the program. ${ }^{47}$ Ironically though, the embassy representative told our team that the State Department had just announced that no funding would be available for trafficking in Kazakhstan for 2004. Even more surprising and puzzling, however, was how the 2003 TIP Report ranked Kazakhstan. Though no funds were being made available to assist the country, Kazakhstan was demoted Tier 2 to Tier 3 and tersely described as "limited by lack of resources, police corruption and difficulty monitoring its borders" (TIP 2003). That May, the majilis approved additions to the country's criminal code specifying punishments for human trafficking and Kazakhstan's president signed the bill into law in July (Interfax Kazakhstan). In September 2003, Presidential Determination No. 35 upgraded Kazakhstan to the rank of Tier 2. But while action by the Bush administration upgraded Kazakhstan to Tier 2, the Master Narrative, written on the State Department's website, continued to represent Kazakhstan as a Tier 3 country. Kazakhstan remained de facto at this lowest rank for almost a year, until the 2004 TIP Report, when it was placed in yet a new category, on a special Watch List, below Tier 2. Upon learning this, the anthropologist in me was impressed at how the master narrative re-asserted itself and exercised new forms of authority with a uniquely liminal category like a "watch list." Victor Turner (1967) has shown how liminal states of being infuse rituals with their power to mark transformation. Liminality is inherently dangerous because of its "in-betweenness," a condition of "nowhereness." Here, the anti-trafficking master narrative inverts this condition, utilizing the liminal category as a holding pattern, and as an assertion of domination. Over the decade that the TIP report has been issued, Kazakhstan has moved back and forth from Watch List to Tier Two in a perpetual state of non-compliance. Over the same decade, the United States has sought airbases on Kazakhstani territory to augment access to Afghanistan and was rebuffed by Nazarbayev and has negotiated for specific pipeline routes through Turkey for better access to Kazakhstan's Tengiz oil production.

\section{Conclusion}

The US counter-trafficking narrative intersects with a host of emerging arrangements of capital, migration and geopolitical relationships in flux at the end of the twentieth and beginning of the twenty-first century. Research from Bosnia and ethnographic data from Kazakhstan provide more complex views of the local manifestations of what is being called global human trafficking. In Bosnia, one sees the aftermath of a serious and troubling development in which women were sexually exploited and a structure of foreign aid and stabilization strategies that supported, in very specific ways, this exploitation. In Kazakhstan, the elements of desperation that

\footnotetext{
47 We also learned that at the time of the workshop, an additional assessment of the issue was being conducted in the entire Central Asian region by an official from the US Justice Department. Her assessment concluded that, in Kazakhstan and in other Central Asian states, there did not appear to be a trafficking problem to the degree and scope of other regions of the world.
} 
drive victims to exploitation, albeit on a significantly smaller scale, have ethnic overtones and have emerged alongside other perhaps more pressing crime problems. Moreover, Kazakhstan itself remains neutral presence in terms of the region's main powers of Russia and China.

While trafficking in persons is hardly a myth, the official narrative put out by its US and international stakeholders is, arguably, the stuff of legend. ${ }^{48}$ Brunvand (1989) reminds us that urban legends play on societal and cultural fears and anxieties. He argues that like myths, these legends circulate as moral lessons, told from person to person using themes and images of plausible, but personally unimaginable situations. ${ }^{49}$ With its accounts of personal suffering linked with simplistic country rankings, the US government and anti-trafficking advocacy groups perhaps promote a global legend, making victims iconic while keeping states liminal. Such rankings depict countries as disorderly and corrupt, suggesting that the victimization of trafficking in humans results from these uncivilized states, and like the myths of any religious tradition allow those that rank to present themselves as the remedy to the problem.

Susan Ehrlich (2010) has argued that we perhaps need overarching master narratives precisely to elicit "uptake" by the law enforcement community, a justice system, or by society at large. Drawing on Brison (2003) work, Ehrlich notes that especially considering certain gender crimes, such a rape or domestic violence, one of the problems missing from the public's conceptualization of the severity of the issue is the fact that there exists no common articulation of outrage. For example, the holocaust and other genocides offer a historical framework of shared experience or a cultural metric with which to measure a crisis of common identity or of the public good. In this sense, master narratives, like that produced by the antitrafficking movement, can function to "tell a story" - to link the individual with the larger immediacy of the collective. No doubt, as such a narrative develops and as the problem is named and defined, there is the conundrum of limiting what belongs or what an experience or a trauma should be called. Through definitions one also finds the conundrum of oppression. The additional danger in telling "the story" or in defining the problem so that it achieves "uptake," is that there is precious little room for revision, a situation that Errol Morris (2012) has called "the prison of ... narrative." 50

At the same time, in challenging the veracity of the data and in assessing the claims of the dominant discourse on human trafficking, critics risk being accused of moral relativism, and losing public sympathy for what are necessarily complicated

\footnotetext{
${ }^{48}$ The State Department has begun to acknowledge how human trafficking can be misconstrued. In a section titled Costs of Myths and Misconceptions about Trafficking in Persons, the 2012 TIP Report states "Domestic law enforcement, not border interdiction, is usually what catches traffickers and frees victims from modern slavery" (TIP 2012:27).

49 See also Levi-Strauss (1995), Geertz (1974) and Malinowski (1962) on the significance of symbols and myths as these circulate within cultural systems as moral codes, rules of normativity and portals to the sacred.

${ }^{50}$ Morris actually uses the term false narrative in critiquing the veracity of the story of Jeffery MacDonald, calling into question not only the trial evidence but versions of the narrative by reporter Joe McGinnis (1983) and the investigative journalist and legal writer Janet Malcolm (1990).
} 
victims that so easily get conceptualized within the neoliberal frameworks of late capitalism and its attending notions of justice as rights (Bernstein 2010). To understand the dominant discourse of human trafficking, we clearly need to connect it to other cultural processes and to the actual arenas in which international and domestic policies intersect with both violence against women, in general, and other types of victimization and criminalization and the larger political contexts in which these ideas disseminate. In this paper, I have tried to show how these ethnographic approaches can reveal not only how a master narrative operates, but what happens beneath it, and to consider our representations of human trafficking versus the nuances in specific sites so that better interventions can be marshaled to respond to human trafficking beyond discourse.

Acknowledgments Field research for this paper was made possible in part by grants from the National Science Foundation Law and Social Science Program, SES\#0111405, and from the Bureau for International Narcotics and Law Enforcement Affairs (INL), \#S-OPRAQ-98-H-N163. Bosnian field research was supported by an International Research and Exchanges Board (IREX) Policy Connect Grant, Jacqueline Berman, PI, July 2006. The views expressed in this paper are the author's and do not necessarily represent the views of the US State Department, The National Science Foundation or IREX. The author would like to thank Anthony Marcus, Arthur DiFuria, Cotten Seiler, Claire Bowen, Shonna Trinch, Kirk Dombrowski and two anonymous reviewers for their generous input and comments on earlier drafts of this article.

Open Access This article is distributed under the terms of the Creative Commons Attribution License which permits any use, distribution, and reproduction in any medium, provided the original author(s) and the source are credited.

\section{References}

Adams, C. 2002. Was there really such as thing as white slavery? The Straight Dope. http://www. straightdope.com/columns/read/1302. Accessed 13 October 2012.

Agustin, L.M. 2007. Sex at the margins: Migration, labour markets and the rescue industry. London: Zed.

Andreas, P. 2008. Blue helmets and black markets: The business of survival in the siege of sarajevo. Ithaca, NY: Cornell University Press.

Bakhtin, M. 1986. The problem of speech genres. In Speech genres and other late essays, ed. C. Emerson, and M. Holquist, 60-102. Austin: University of Texas Press.

Bales, K. 2004. Disposable people. Berkeley: University of California Press.

Bamberg, M. 2003. Positioning with Davie Hogan-Stories, Tellings, and Identities. In: Narrative analysis: Studying the development of individuals in society, ed. C. Daiute, and C. Lightfoot, 135-157. London: Sage.

Bamberg, M., and M. Andrews. 2004. Considering counternarratives: Narrating, resisting, making sense. Amsterdam: John Benjamins.

Berman, J. 2006. The left, the right, and the prostitute: The making of US antitrafficking in persons policy. Tulane Journal of International and Comparative Law 14(2): 269-293.

Berman, J. 2008. Personal communication.

Bernstein, E. 2010. Militarized humanitarianism meets carceral feminism: The politics of sex, rights, and freedom in contemporary anti-trafficking campaigns. Signs: Journal of Women in Culture and Society 36(1): 45-71.

Beverly, J. 1993. Against literature. Minneapolis: University of Minnesota Press.

Bloch, A. 2003. Victims of trafficking or entrepreneurial women? Narratives of post-Soviet entertainers in Turkey. Canadian Women's Studies 22(3-4): 152-159.

Brison, S.J. 2003. Aftermath: Violence and the remaking of the self. Princeton: Princeton University Press. 
Brooklyn Law School. 2012. Symposium: Writing the master narrative for U.S. health policy. www.brooklynlaw.edu/health. Accessed 12 October 2012.

Brunvand, J. 1989. The vanishing hitckhiker: American urban legends and their meanings. New York: W.W. Norton.

Campion-Vincent, J. 2001. On organ theft narratives. Current Anthropology 42(4): 555-556.

Cavanagh, S. 2008. Sexing the teacher: School sex scandals and queers pedagogies. Seattle: University of Washington Press.

Cohen, S. 1972. Folk devils and moral panics. New York: St. Martin's Press.

Craumer, P. 1992. Agricultural change, labor supply and out-migration in Soviet Central Asia In: Geographic Perspectives on Soviet Central Asia, ed. R. Lewis, R. Churchill, and A. Tate, 129-147. New York: Psychology Press.

Dawson, A. 2008. Postwar settlements and the production of new illegalities: The case of dayton and people trafficking and prostitution in Bosnia and Herzegovina. Dialectical Anthropology 32(1-2): $123-137$.

Doezema, Jo. 2000. Loose women or lost women? The re-emergence of the myth of white slavery in contemporary discourses of 'trafficking in women. Gender Issues 18(1): 23-50.

Douglas, M. 1969. Purity and danger: An analysis of concepts of pollution and taboo. London: Routledge and Kegan Paul.

Ehrlich, S. 2010. Discussant remarks. Representing resistance and resilience $\mathrm{n}$ the context of sexual assault. Annual meeting of the American Anthropological Association, Montreal, November 17.

Erler, M.C. 2003. Gendering the master narrative: Women and power in the middle ages. Ithaca: Cornell University Press.

Farrell, A., and S. Fahy. 2009. The problem of human trafficking in the US: public frames and policy responses. Journal of Criminal Justice 37: 617-626.

Fiengold, D.A. 2010. Trafficking in numbers: The social construction of human trafficking data. In Sex, drugs and body counts: The politics of numbers in global conflict and crime, ed. P. Andreas, and K. Greenhill, 46-74. Ithaca: Cornell University Press.

Florida State University (FSU) International Center for the Advancement of Human Rights. 2003. Florida responds to human trafficking. Report on Trafficking Victims in Florida.

Foucault, M. 1972. The archeology of knowledge. New York: Pantheon.

Friman, H.R. 2010. Numbers and certification: Assessing foreign compliance in combating narcotics and human trafficking. In Sex, drugs and body counts: The politics o numbers in global conflict and crime, ed. P. Andreas, and K. Greenhill, 75-109. Ithaca: Cornell University Press.

Gaddis, J. 2011. George F. Kennan: An American life. New York: The Penguin Press.

Geertz, C. 1973. The interpretation of cultures. New York: Basic Books.

Geertz, C. 1974. Myth, symbol and culture. New York: W.W. Norton and Company.

Gikandi, S. 2001. Globalization and the claims of post-coloniality. South Atlantic Quarterly 100(3): 627-658.

Goode, E., and N. Ben-Yehuda. 1994. Moral panics: The social construction of deviance. Cambridge, MA: Blackwell.

Government Accountability Office 2006. Human trafficking: Better data, strategy, and reporting needed to enhance US antitrafficking efforts abroad. GAO-06-825, July.

Greenhill, K.M. 2010. Counting the cost: The politics of numbers in armed conflict. In Sex, drugs and body counts: The politics of numbers in global conflict and crime, ed. P. Andreas, and K. Greenhill, 127-158. Ithaca: Cornell University Press.

Hackett, R.A., and Y. Zhao. 1994. Challenging a master narrative: Peace protest and opinion/editorial discourse in US press during the gulf war. Discourse and Society 5(4): 509-541.

Harley, J. B. 1988. Maps, knowledge and power. In: The Iconography of Landscape, ed. D. Cosgrove and S. Daniels, 277-312. Cambridge: Cambridge University Press.

Harper, K. 2001. Environment as master narrative: Discourse and identity in environmental problems. Anthropological Quarterly 74(3): 101-103.

Hayden, R. 2008. Comment: Post-war settlements and the production of new illegalities. Dialectical Anthropology 32(1-2): 143-146.

Hierman, B. 2004. Internal migration in Central Asia: A comparative case study of rural- urban migration to Astana and Tashkent. Paper presented at the Eleventh Annual Central Eurasian Studies Conference. April 3, Bloomington, Indiana.

Hodge, S. 2011. Trafficked: The diary of a sex slave. Sibel Hodge: Self-Published. 
Joseph, G. 2003. Tulsa 'slavery' case is classic example of human trafficking says expert. India Abroad. (New York edition). New York, NY September 26, 23, no 52, p. A12.

Junger, S. 2002. Slaves of the brothel. Vanity Fair. July, 112-166.

Kempadoo, K., J. Sanghera, and B. Pattanaik, (eds.). 2005. Trafficking and prostitution reconsidered: New perspectives on migration, sex work, and human rights. Boulder, Colo.: Paradigm.

King, L.E., and J.M. Ray. 2000. Developing transnational law enforcement cooperation. Journal of Contemporary Criminal Justice 16(4): 386-409.

Korobkov, A.V., and Z.A. Zaionchkovsaia. 2004. The changes in the migration patterns in the post-Soviet states: The first decade. Communist and Post-Communist Studies 37(4): 481-508.

Kramer, A. 2010. In Asia, a gulf's worth of oil awaits transport. New York Times. July 22.

Landesman, P. 2004. The girls next door. New York Times Magazine, 30-66. January 26.

Levi-Strauss, C. 1995. Myth and meaning. New York: Schocken.

Limanowska, B. 2002. Trafficking in human beings in South Eastern Europe. New York: UNICEF, UNOHCHR, OSCE/ODIHR.

Lindquist, J. 2010. Images and evidence: Human trafficking, auditing and the production of illicit markets in Southeast Asia and beyond. Public Culture 22(2): 223-236.

Lyotard, J.-F. 1984. The postmodern condition: A report on knowledge (trans: Bennington, G., and Massumi, B.) Minneapolis: University of Minnesota Press.

Makkai, T. 2003. Critique of papers on human trafficking. PNI workshop, UN crime commission, Vienna, 15th May.

Malcolm, J. 1990. The journalist and the murderer. New York: Vintage.

Malinowski, B. 1962. Sex, culture and myth. New York: Harcourt, Brace and World.

McGinnis, J. 1983. Fatal vision. New York: Putnam.

Menchu, R. 2010. I, Rigoberta Menchu: An Indian woman in Guatemala (Second Edition). London: Verso.

Mendelson, S.E. 2005. Barracks and brothels: Peacekeepers and human trafficking in the Balkans. Washington, DC: CSIS.

Montgomery, H. 2001. Imposing rights? A case study of child prostitution in Thailand. In Culture and rights: Anthropological perspectives, ed. J. Cowan, M.-B. Dembour, and R. Wilson, 80-101. Cambridge: Cambridge University Press.

Montgomery, H. 2011. Rumours of child trafficking after natural disasters. Fact, fiction or fantasy? Journal of Children and Media 5(4): 395-410.

Morris, E. 2012. Wilderness of error. New York: Penguin Press.

Murray, A. 1998. Debt-bondage and trafficking: Don't believe the hype. In Global Sex Workers: Rights, Resistance and Redefinition, ed. K. Kempadoo and J. Doezema. New York: Taylor Francis Inc.

Nathan, D. 2005. Oversexed. August: The Nation. 11.

Nazpary, J. 2001. Post-soviet chaos: Violence and dispossession in Kazakhstan. New York: Pluto Press.

Nelson, J.W. 2011. Daughters: The heartbreak of human trafficking. James W. Nelson (Self- published).

Norrick, N. 2000. Conversational narrative: Story-telling in everyday talk. Amsterdam: John Benjamins Publishing.

Opotow, S. 1990. Moral exclusion and injustice: An introduction. Journal of Social Issues 46(1): 1-20.

Piper, N. 2003. Feminization of labor migration as violence against women: International, regional and local non-governmental organization responses in Asia. Violence Against Women 9(6): 723.

Public Law 106-386. 2000. October 28. http://www.state.gov/documents/organization/10492.pdf. Accessed 17 September 2012.

Roberts, C., and S. Sarangi. 2003. Uptake of discourse research in interprofessional settings: Reporting from medical consultancy. Applied Linguistics 24(3): 338-359.

Rothschild, N. 2009. More evidence that trafficking is a myth. Spiked. 26 October. http://www.spike-online.com/index.php/site/article/7625.

Schatz, E. 2004. Modern clan politics: The power of "Blood" in Kazakhstan and Beyond. Seattle: University of Washington Press.

Schegloff, E.A. 1982. Discourse as an interactional achievement: Some uses of 'Uh huh' and other things that come between sentences. In: Georgetown University roundtable on Languages and linguistics, 1981: Analyzing discourse: Text and talk, ed. D. Tannen, 71-93. Washington, D.C.: Georgetown University Press.

Scheper-Hughes, N. 2001a. Commodity fetishism in organs trafficking. Body and Society 7(2-3): 31-62. Scheper-Hughes, N. 2001b. Reply. Current Anthropology 42(4): 556-558. 
Schloenhardt, A. 1999. Organized crime and the business of migrant trafficking: An economic analysis. Crime, Law and Social Change 32(3): 203-233.

Shelley, L. 1994. Crime and the collapse of the Soviet state. In: The Social Legacy of Communism,. ed. J. R. Millar, and S. Wolchik, 130-148. Cambridge: Cambridge University Press.

Snajdr, E., and D. Vyortkin. 2001. Domestic violence and police training. Crime and Justice International 17(53): 1-6.

Snajdr, E. 2005. Gender, power and the performance of justice: Muslim women's responses to domestic violence in Kazakhstan. American Ethnologist 32(2): 294-311.

Snajdr, E. 2006. Creating police partnerships in Kazakhstan through U.S.-funded domestic violence training. In Democratic Policing in Transitional Societies, ed. N.W. Pino and M.D. Wiatrowski, 179-197. New York: Ashgate.

Snajdr, E. 2007. Ethnicizing the subject: Domestic violence and the politics of primordialism in Kazakhstan. The Journal of the Royal Anthropological Institute 13: 603-620.

TIP Report U.S. Department of State (Annually 2001-2012).

Trinch, S. 2003. Latina's narratives of domestic abuse: Discrepant versions of violence. Amsterdam: John Benjamins.

Trinch, S. 2010. Risky subjects: Narrative, literary testimonio and legal testimony. Dialectical Anthropology 34(2): 179-204.

U.S. Department of Health and Human Services. 2011. National diabetes statistics. diabetes.niddk.nih.gov. Accessed 14 September 2011.

Utrecht. 1994. Conference on traffic in persons. Netherlands: Utrecht.

Vandenberg, M. 2002. Hopes betrayed: Trafficking of women and girls to post-conflict Bosnia and Herzegovina for forced prostitution. Human Rights Watch 14(9): 1-72.

Wallerstein, I. 1974. The Modern World System: Capitalist Agriculture and the Origins of the European World-Economy in the 16th Century. New York: Academic Press.

Warner, M. 2005. Publics and counter publics. New York: Zone Books.

Warren, K. 2010. The illusiveness of counting 'victims' and the concreteness of ranking countries: Trafficking in persons from Columbia to Japan. In Sex, drugs and body counts: The politics of numbers in global conflict and crime, ed. P. Andreas, and K. Greenhill, 110-126. Ithaca: Cornell University Press.

Wedel, J.R. 2001. Collision and collusion: The strange case of Western Aid to Eastern Europe. New York: Palgrave.

Weitzer, R. 2007. The social construction of sex trafficking: Ideology and institutionalization of a moral crusade. Politics and Society 35(3): 447-475.

Weitzer, R. 2012. Sex trafficking and the sex industry: The need for evidence-based theory and legislation. The Journal of Criminal Law and Criminology 101(4): 1337-1369.

Zhang, S., and K.-L. Chin. 2002. Enter the dragon: Inside Chinese human smuggling organizations. Criminology 40(4): 737-768. 